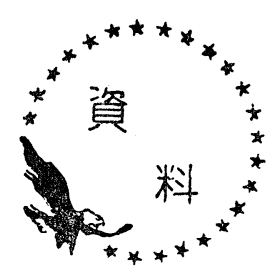

1. 試作研究の目的

わが国の家庭用の暖房装置は最近急激に変化しつつ ある。ポータブル式石油ストーブの爆発的な普及にひ きつづいて, 温水または温風による家屋全体の暖房が 考えられるよらになつてきた。

現在主として灯油を燃料とする家庭暖房（給湯む兼 数る）用温水器が市販されているが，石炭などの固体 然料を用いるものはほとんどないようである。石炭は 家庭用燃料としていくつかの利点を持ち，風呂用， ス トーブ用などとして現在もかなりの需要がある。そこ でその利点を生かした石炭燃焼の温水器を開発する目 的でこの試作研究が行なわれた。

石炭は家庭用燃料としてつぎのような利点を有す る。

（i）貯蔵が容易で安全である。

（ii）灯油などその他の家庭然料にくらべて価格が 低以。

しかし一方つぎのような問題点がある。

(i) 点火, 給炭, 灰処理に手間がかかり, 灰の処 分方法も考㝋なければならない。

（ii）燃焼排ガスを排出させるために煙突を必要と

し，燃焼状態がわるいと煙によつて近隣に迷惑を およぼすおそれがある。

取扱かいに手間がかからないよらにするためにはで きるだけ自動操作にする必要がある。さいわい近年に なつて事務所用の温風暖房器として下込燃燒による自 動然焼装置を有し，ほとんど煙を発しない燃燒を行な らものが開発された。今回の試作温水器の燃焼機とし てそれを利用することとした。温水出口温度を一定に 保つようにオンオフ動作で自動的に燃焼制御すること ができる。

この温風器は事務所などある程度広い一室の暖房を 行ならために用いられているが，わが国の家庭では一 般に比較的小さな部屋に分れているのでそのまま用い ることはできない。また温風をダクトで配分するより は温水を用いた方が各部屋を別々に暖房するのに有利 である。さらにわが国の家庭構造は煙突が家の中央に

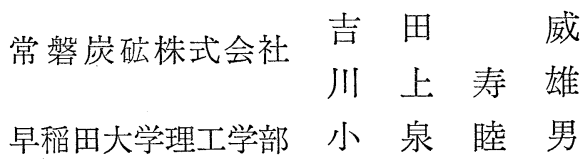

設置されていることがほとんどなく，その点からも温 水器を家の片隅に掠いて暖房を行ならのが最も利用し やすい形であろら。

以上のような考方方で従来の温風器の熱交換部のか わりに試作した温水器をとりつけ, その性能の測定が 行なわれた。試作に当たつては石炭燃燒の特徵である 燃料費の低いことを生かすため十分高い効率をもち， その大きさは従来の温風機と異ならないように注意が はらわれた。

\section{2. 温水器の構造}

2-1 水管式温水器

図 1 亿試作した水管式温水器の構造を示す。これは 常磐炭砿株式会社で発売している温風暖房器「スーパ 一ヒータ」の温風熱交換器の部分をとりはずして図 1 の正面図右側および側面図に示されるよらな温水器を とりつけたものである。

石炭はホッパ(1)からスクリュー(2)でレトルト (3)に送 られ，送風機(4から送られた空気によつて燃燒する。 水は入口管(5からはいり, 水管(6をとおつて後側面に 出て, さらに左右の側面をとおつて上昇し, 上面から 出口管(7)をとおつてとり出される。

この温水器の主要諸元はつぎのとおりである。 ホッパ容量 $100 l$

スクリュー 軸径 $19 \mathrm{~mm}$, 外径 $52 \mathrm{~mm}$, ピッチ $470 \mathrm{~mm}$, 全長約 $400 \mathrm{~mm}$

燃焼 量 $3.4 \sim 3.8 \mathrm{~kg} / \mathrm{hr}$

温水器伝熱面積 $\quad 1.08 \mathrm{~m}^{2}$

保有水量 $75 l$

2-2 煙管式温水器

水管式温水器の実験を行なつた結果, それを改良す る目的で煙管式温水器が製作された。その構造を図 2 に示す。

燃燒系統は前の場合と同様で，水は下部の入口管(5) からはいり上部の出口管(7)から出る。その他番号は図 1 と同じであるが，(6)㖶管を示す。

\section{3. 実験方法}

この温水器の性能実験のために図 3 亿示すような系 


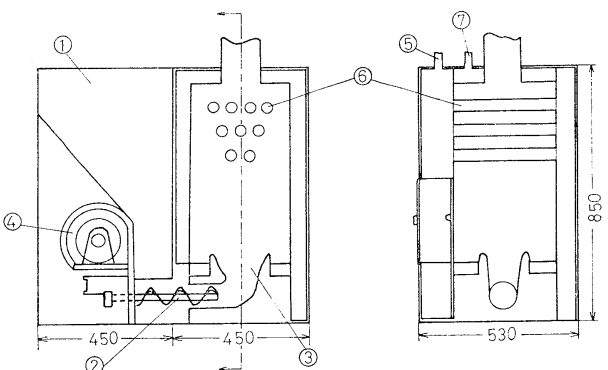

図 1 水管式温水器

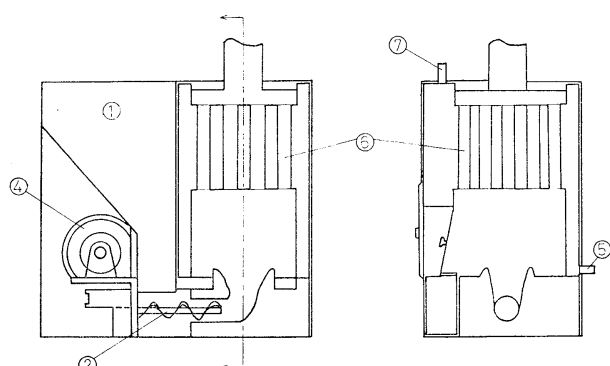

図 2 煙管式温水器

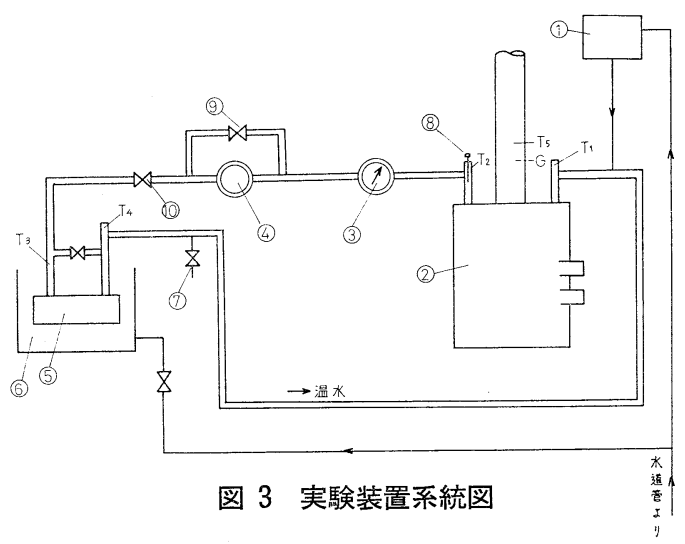

統が組まれた。

シスターンタンク (1)はボールタップにより常に一定 水位に保たれ, そこから水の配管が温水器入口に接続 されている。温水器(2)で加熱された水は流量計(3)と温 水循環ポンプ(4)をと叔つて放熱器(5)供給される。放 熱器汸水槽(6)にひたされ, 水槽に供給する水の量を変 化させることにより, 放熱器で奪われる熱量を調節す ることができる。給湯として温水を消費するときの実 験のために弁(7)が設けられている。

温水器出口には温度調節器(8)が挿入されている。温
水温度が設定温度 (約 $\left.80^{\circ} \mathrm{C}\right)$ 以上になると燃料と燃焼 用空気の供給が停止する。調節器には $4 \sim 5 \operatorname{deg}$ の不 感帯があり，それより温度が低下寸ると燃料と空気の 供給が再開する。したがつて燃焼量は放熱器の熱負荷 に応じて自動的に定まる。

燃焼用空気量は送風機入口のダンパによつて調整さ れる。また煙突にもダンパを設け，炉内圧の調整を行 なつた。実験に際しては漏入空気をできるだけ少なく するため, 燃焼室から燃焼ガスがふき出さない程度に 煙突ダンパをできるだけしぼつて運転した。

温水循環量はポンプのバイパス弁(9) と放熱器前の弁 (10によつて $500 \sim 2000 \mathrm{l} / \mathrm{hr}$ の範囲に調節された。

温水器の性能に対して最も大きな影響を持つ因子は 熱負荷 (放熱器で奪う熱量) と空気過剩係数の二つで あると思われる。これに対し温水循環量の影響はあま りないことが実験結果からも認められる。

温水器の性能としては熱効率と伝熱面の熱通過率を 中心にして考える。これら性能值を求めるために, 図 3 亿拉りる $\mathrm{T}_{1}, \mathrm{~T}_{2}, \mathrm{~T}_{3}, \mathrm{~T}_{4}$ の位置で温水温度を $\mathrm{CC}$ 熱電対で測定する。温水流量はオーバル流量計(3)で測 定される。図 3 の Gの位置から燃燒排ガスが採取され て, オルザート分析器でその組成が分析される $\mathrm{T}_{5}$ の 位置には C A 熱電対が捕入され，排ガス温度が測定さ れる。

実験は一つの条件について定常状態で 1.5 時間程度 行ない, この間のホッパ内の石炭の減少量を求めた。 この值はスクリューを連続運転したときの石炭の送り 量にスクリニーがオンになつている時間の割合を乗じ たものにほぼ等しい。

使用石炭は鹿島特粉で, その組成と発熱量は表 1 亿 示される。

\section{表 1 使用炭（鹿島特粉）の組成と発熱量}

$\begin{array}{lcc}\text { 炭 } & \text { 素 } & 63.6 \% \\ \text { 水 } & \text { 素 } & 5.2 \\ \text { 酸 } & \text { 素 } & 11.1 \\ \text { 窒 } & \text { 素 } & 0.8 \\ \text { 燃焼性イオウ } & 3.0 \\ \text { 水 } & \text { 分 } & 5.1 \\ \text { 灰 } & \text { 分 } & 11.2\end{array}$

低発熱量 $6300 \mathrm{k} \mathrm{cal} / \mathrm{kg}$

\section{4. 実験結果}

4-1 測定結果の整理

全負荷のとき以外はオンオフ運転となる。オフ時の 
排ガス組成は酸素が著しく多く，炭酸ガスが少ない。 これは屝口などからの少量の漏入空気によるものと思 われるが，その量はオン時の燃焼ガス量とくらべて遙 かに少ないので, 燃焼ガス量の計算はオン時のみにつ いて行ない，それにもとづいて排ガス損失熱量 $q_{2} \mathrm{kcal}$ / hr を求めた。

温水に伝えられた熱量は温水器入口, 出口の温度差 と温水流量から求められ，これを $q_{1} \mathrm{kcal} / \mathrm{hr}$ とする。 供給された石炭の発熱量の総和を $q_{0} \mathrm{kcal} / \mathrm{hr}$ とする と

$$
q_{3}=q_{0}-q_{1}-q_{2}
$$

でその他の損失熱量が求められる。この中には放熱損 失と末燃分による損失熱が含まれる。

熱効率 $\eta \%$ は

$$
\eta=q_{1} / q_{0} \times 100
$$

である。

熱通過率導出に必要な燃焼ガスと温水との温度差に ついては, 温水の入口, 出口温度, 排ガス出口温度が 測定されている。燃燒ガス入口温度は測定できないの で，その時の空気過剩係数における理諭然燒温度を燃 焼ガス入口温度と考えることにした。このようにして 平均温度 $\Delta t_{m}$ 差が求められると, 熱通過率 $K \mathrm{kcal} /$ $\mathrm{m}^{2} \mathrm{hr} \operatorname{deg}$ 沈次式によって求めることができる。

$$
K=\frac{q_{1}}{F / \Delta t_{m}}
$$

ここでFは伝熱面積である。

この式で前記の $q_{1}$ の值をそのままいれたときの熱 通過率を $K_{1}$ とすると, これはオフ時間も含めた全運 転時間に対する熱通過率となる。しかし燃焼がオフに なつている間は燃焼ガスの流れがないので，伝熱もほ とんどないものと考えられる。そこで然焼がオンにな つているときのみの熱通過率として

$$
K_{2}=K_{1} / \varphi
$$

を求める。ここで $\varphi$ は全運転時間に対する燃焼がオン になつている時間の割合である。

4-2 水管式温水器の実験結果

(i) その他の損失熱の入熱に対する割合 $q_{3} / q_{0}$ と 空気過剩係数 $m$ との関係が図 4 に示される。 $m>2.0$ ではほぼ一定の值を示すが， $m<2.0$ では急に上昇し ている。これは送風量の減少のため未燃損失が増大し たものと思われる。

(ii) 熱効率 $\eta$ と空気過剩係数 $m$ との閒には図 5 に 示すような関係がある。 $m=2.0$ 付近で最大効率を示 すことがみとめられる。

（iii）熱効率 $\eta$ と熱負荷 $q_{1}$ との関係をみると図 6

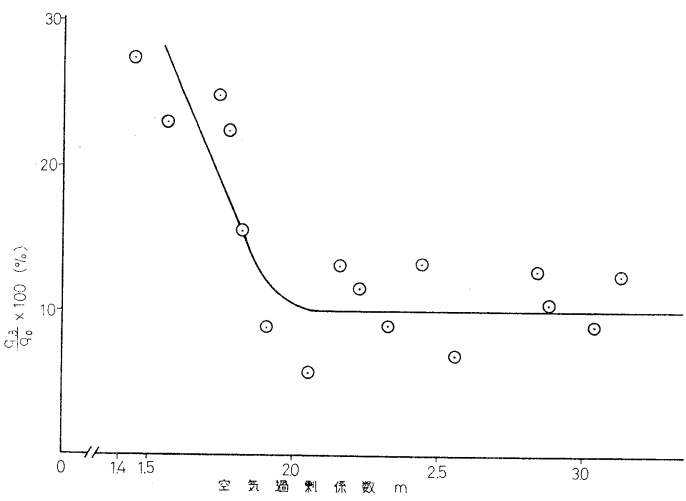

図 4 水管式温水器におけるその他の損失熱（放 熱損失十末燃損失）の割合と空過剩係数の 関係

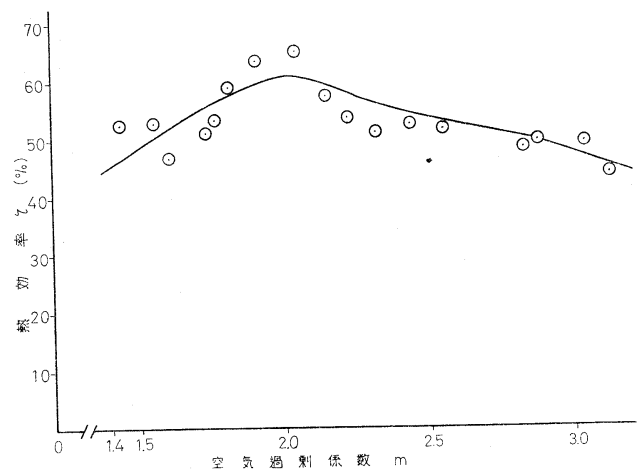

図 5 水管式温水器における熱効率と空気過剩係 数との関係

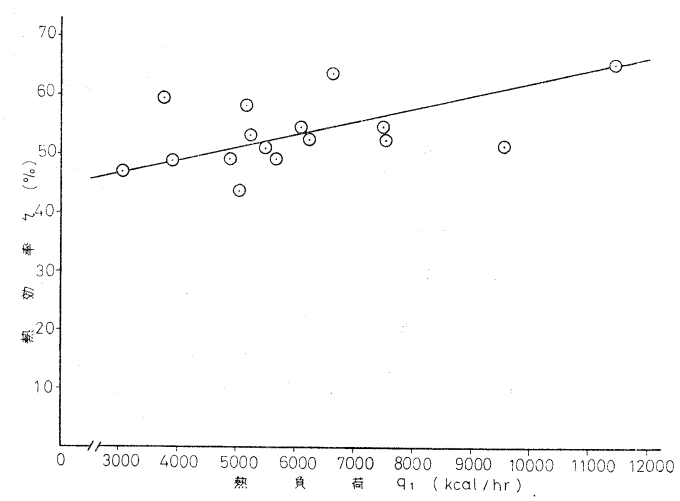

図 6 水管式温水器における熱効率と熱負荷の関 係 


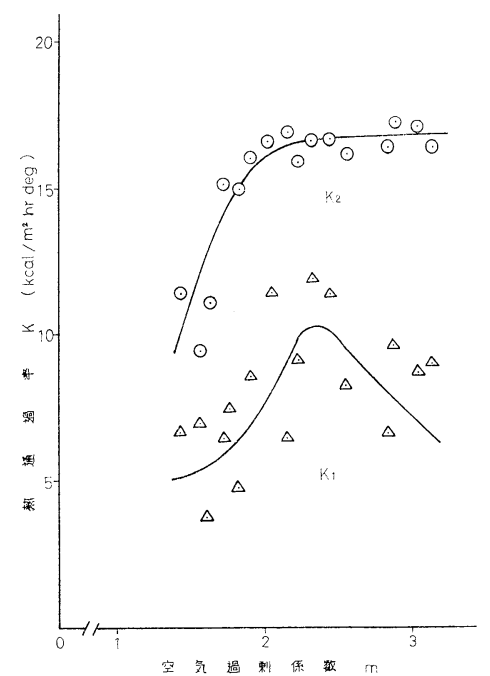

A : 全運転時閒について求めた熱通過率 $K_{1}$ ○:オン時閒のみについて求めた熱通過率 $K_{2}$

図 7 水管式温水器における熱通過率と空気過剩係 数との関係

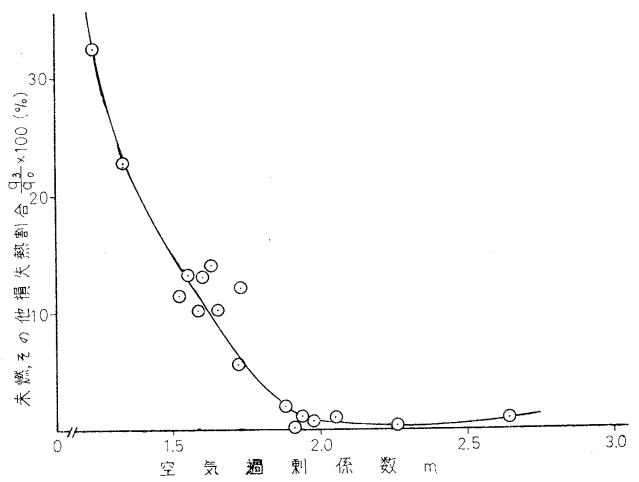

図 8 煙管式温水器における未燃その他の損失熱 割合と空気過㮃係数との関係

に示すようになる。連続燃焼を行ならボイラでは最大 の熱効率を示す負荷が存在するのが普通であるが，こ の温水器はオンオフ運転のためオフ時間が長い低負荷 の方が効率が低下している。

(iv) 熱通過率 $K$ と空気過剩率 $m$ との関係は図 7 に 示されるようになる。ここで全運転時閒に対する $K_{1}$ は大きくばらついているのに対し，オン時間のみにつ いて算出した $K_{2}$ は $m>2.0$ でほぼ一定の值 $16.5 \mathrm{kcal}$ $/ \mathrm{m}^{2} \mathrm{hr}$ deg を示す。 $m>2.0$ で $K$ が低下しているの は不完全然焼を考慮しないため, 燃焼ガス 入口温度

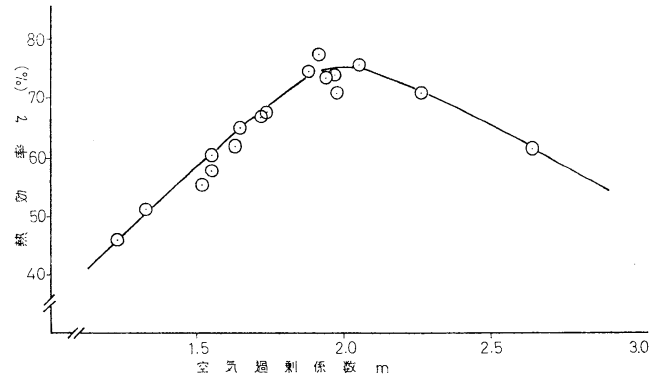

図 9 煙管式温水器における熱効率と空気過剩係 数の関係

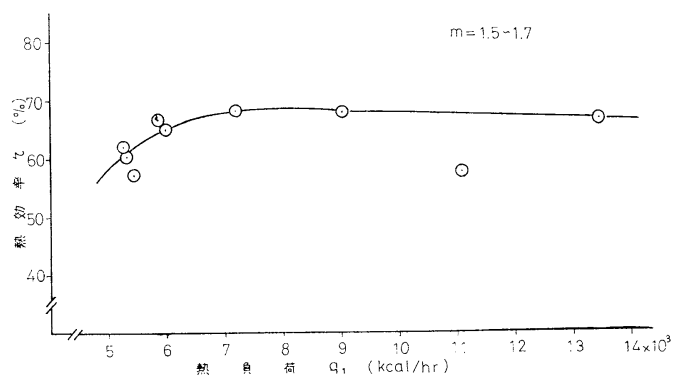

図10 煙管式温水器における熱効率と熱負荷の関 係

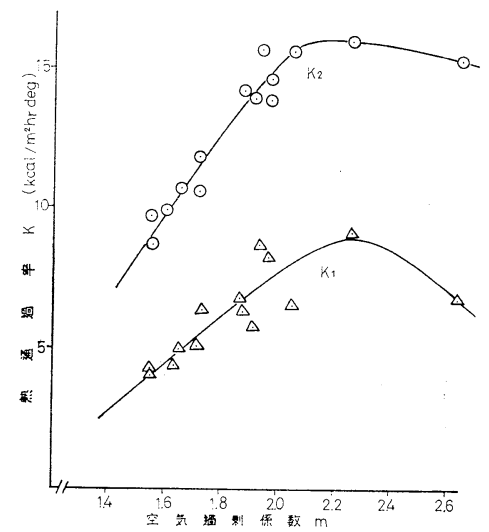

図11 煙管式温水器における熱通過率と空気過剰 係数の関係

（計算による温度）を実際より高くみつもつているか らであろら。

4-3 煙管式温水器の実験結果

(i ) その他の損失の割合 $q_{3} / q_{0}$ と空気過剩係数 $m$ の関係が図 8 に示される。 $m>2.0$ で一定となるがそ の值は前の場合より小さい。これは未燃損失が減少し たことよりは，この実験に使用した燃料の発熱量が前 
の実験よりいくらか高かつたためではないかと思われ る。

(ii) 熱効率 $\eta$ と空気過剩係数 $m$ の関係は図 9 亿示 される。やはり $m=2.0$ 付近で最大值を示す。

（iii）熱効率 $\eta$ と熱負荷 $q_{1}$ の関係は図10に示され る。空気過剩係数が $1.5 \sim 1.7$ の範囲にあるものをと つたもので, 半負荷程度まで注としん゙一定の効率を 示している。

（vi） 熱通過率 $K$ と空気過剩係数 $m$ との関係は図 11 に示される。前の場合之同様の傾向がみられるが，一 定值となる所で $K_{2}=16 \mathrm{kcal} / \mathrm{m}^{2} \mathrm{hrdeg}$ 程度である。

\section{5. 実験結果の検討}

押込通風の石炭燃焼ではこの程度の小形温水器でも $75 \%$ 程度の熱効率をうることが可能であろう。少なく とも70\%程度の効率をあげてはじめて低価格の燃料と いう特徴が生かされる。しかしこの試作研究の場合に は温水器自体をある大きさの中にはめこむことが要求 され，そのため十分な伝熱面積をとることが困難であ つた。はじめの水管式温水器では $60 \%$ 程度の効率しか 得られなかつたので，つぎに伝熱面積を大きくとりや すい煙管式のものが製作された。煙管式温水器では空 気過鄱係数 2.0 付近で $79 \%$ の効率が保証されたので, 一応目標值に達したものとみてよいであろう。

下込燃燒機で空気過剩係数 2.0 付近で最高効率を示 しているということは，かならずしも理想的な燃焼状 態ではないことを意味する。その理由の一つとして燃 焼ガスの混合が不十分であることが考えられる。そこ で然焼室内にしぼり板（中央に円形の孔のあいた板） を捕入して燃焼ガスの混合をよくしょらとした。しか し実験の結果からは明膫な効果をみとめることはでき なかつた。空気過剩係数が小さくても燃焼ガス中の未 燃分が少ないことを考え合わせると, 空気過剩係数 2.0 以下で効率が低下するのは主としてもえがら中の 末燃炭素の増加によるものと思われる。

伝熱面の熱通過率は水管式でも煙管式でも近い值と なつた(約 $16 \mathrm{kcal} / \mathrm{m}^{3} \mathrm{hr} \mathrm{deg}$ )。これは同程度の温水器 を設計する場合に信頼して用いることのできる数值と 考えられる。

煙管式温水器は水管式のものとくらべて伝熱面（煙 管および上の鏡板）へのすすの付着が多かつた。これ は燃焼室が小さくなつたことによるものと思われる。 その意味で然燒室内をもら少し高温にして, 燃燒ガス の混合を促進させることが必要である。

\section{6. 実用試験の検討}

2-1 に記した水管式温水器を実用的に家庭において
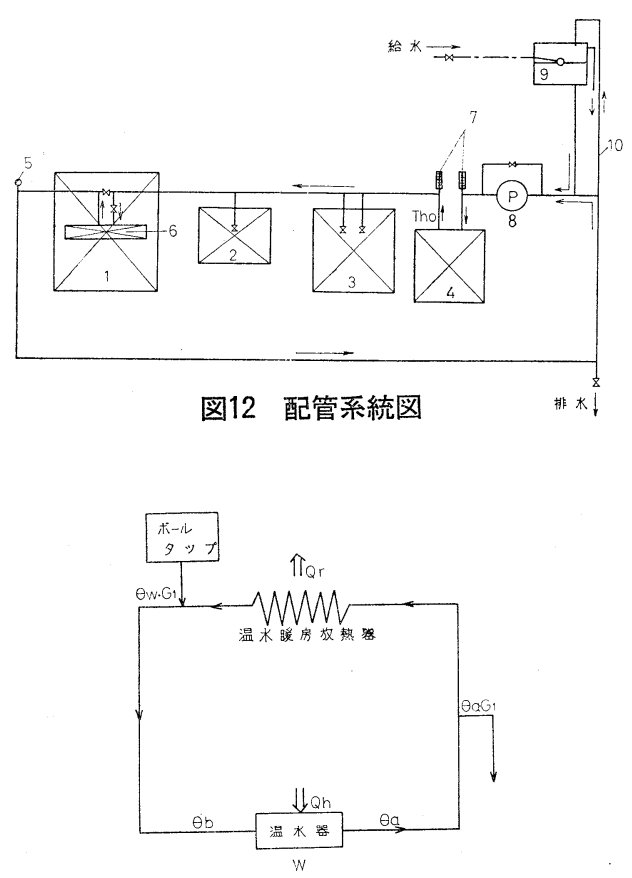

$W$ : 循環系保有水量 [kg]

$\theta_{a}$ : 循環水の温水器出口温度 $\left[{ }^{\circ} \mathrm{C}\right]$

$\theta_{b} ：$ 八口温度 $\left[{ }^{\circ} \mathrm{C}\right]$

$G_{1}:$ 流出水量 $[\mathrm{kg} / \mathrm{hr}$ ]

$\theta_{w}$ : 給水温度 $\left[{ }^{\circ} \mathrm{C}\right]$

$Q_{r}$ ：暖房器による放熱量 [ $\left.\mathrm{kcal} / \mathrm{hr}\right]$

$Q_{h}$ : 温水器による吸熱量 [ $\left.\mathrm{kcal} / \mathrm{hr}\right]$

$\theta_{0}:$ 気 温 $\left[{ }^{\circ} \mathrm{C}\right]$

\section{図13 装置の循環系統図}

の試験をするため一般の家庭に据えつけ試験を行なつ た。今回の試験において温水の使用個所は温水暖房放 熱器（ファン付）を使用した暖房および温水をそのま ま使用する台所・洗面所・風呂の 4 箇所である。温水 は温水器出口の温度を $70^{\circ} \mathrm{C}$ 亿制御し, 温水循環ポン プによつて循環させ, その循環経路に温水暖房放熱器 を入れさらに循環パイプより, 風呂・台所・洗面所に ブランチし，その扔のおのにミキシング・バルブを設 けて, 温水を適温にして利用するようにした。温水循 環系統は図12に示す。

図に虬いて

ポンプ: $4 \mathrm{~m} \times 25 \mathrm{l} / \mathrm{min} .1 \varphi .100 \mathrm{~V} .115 \mathrm{~W}$.

温水暖房放熱器: $850 \times 260 \times 600 \mathrm{~mm}$. $50 \mathrm{~W}$

循環パイプ: 温水器より風呂用ブランチ箇所まで

$25 \mathrm{~mm}$ 径, その他は $20 \mathrm{~mm}$ 径パイプを使用し配

管はすべて $25 \mathrm{~mm}$ の岩綿にて保温した。

試験は実際に使用する立場に立つて実施した。すなお ちサーモスタットにて $70^{\circ} \mathrm{C}$ に制御された温水を流量 
$1,000 \mathrm{l} / \mathrm{hr}$ のラインポンプにて 循環させ 使用箇所 4 箇所で調整しながら，その実用性を検討した。

風呂用として給湯しない場合，日本家屋一間 ( 8 畳) を暖房し，さらに台所洗面所化いて日常使用する程 度の給湯を行なつたが給湯した場合 $10^{\circ} \mathrm{C}$ 位の温度低下 があつたが，サーモスタット作動により，燃焼が始ま

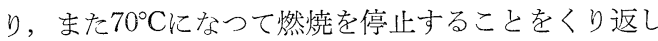
て何ら支障なく使用可能であつた。しかし，風呂用と して給湯した場合（暖房は併用）には温水の温度低下 が著しく, $10 \mathrm{l} / \mathrm{min}$. で 20 分間すなおち $200 l$ の温水 を給湯する予定であつたが，途中で給湯を中止せざる を得なくなつた。この原因としては循環水量が小さか つたため給湯による熱の放出が燃焼からの受熱を上迴 つたことによる。したがつてこの温水器が風吕への給 湯および暖房を満足させるためには循環パイプの途中 にある程度の容量をもつタンクを設備すれば循環水量 も大きくなつて併用が可能となる。

これを簡単な熱の出入の計算からしらべてみる。暖 房, 給湯装置の循環系統図は図13に示されるようにな る。

温水暖房器の放熱量 $Q_{r}$ は， $K_{r}$ を放熱器の熱通過 率 $\mathrm{kcal} / \mathrm{m}^{2} \mathrm{hr}$ deg, $A$ を放熱器の 表面積 $\mathrm{m}^{2}$ とし, 気温を $\theta_{0}{ }^{\circ} \mathrm{C}$ とて

$$
Q_{r}=K_{r} A\left(\theta_{a}-\theta_{0}\right)
$$

またこの循環系の放熱がすべて暖房器によつてなされ るとすると，この循環系のもつ熱量の変化は

$$
\begin{aligned}
& d\left(C W \theta_{a}\right)=C G_{1} \theta_{\omega} d t+Q_{h} d t \\
& \quad-C G_{1} \theta_{a} d t-K_{r} A\left(\theta_{a}-\theta_{0}\right) d t
\end{aligned}
$$

と表わすことができる。C 壮水の比熱 $\mathrm{kcal} / \mathrm{kg} \mathrm{deg}$ で ある。

(2)式を $\theta a$ について解けば

$$
\begin{aligned}
\theta_{a}= & \frac{C G_{1} \theta_{\omega}+Q_{h}+K_{r} A \theta_{0}}{C G_{1}+K_{r} A} \\
& +\frac{C_{0}}{C G_{1}-K_{r} A} e^{-\frac{C G_{1}+K_{r} A}{C W} t}
\end{aligned}
$$

ただし $C_{0}$ は積分定数である

ここで, $G_{1}=10 \mathrm{l} / \mathrm{min} . \times 60=600[\mathrm{~kg} / \mathrm{hr}]$

$$
\begin{aligned}
\theta_{\omega}, & \theta_{0}=10\left[{ }^{\circ} \mathrm{C}\right] \\
Q_{h} & =10,000[\mathrm{kcal} / \mathrm{hr}] \\
C & =1\lceil\mathrm{kcal} / \mathrm{kg} \mathrm{deg}\rceil
\end{aligned}
$$

サーモスタットで調整された温水器出口温度を $\theta a$ 。 $=70^{\circ} \mathrm{C}$, 放熱器の定常熱負荷を $2000 \mathrm{kcal} / \mathrm{hr}$ とすると

$$
\begin{aligned}
& K_{r} A\left(\theta a_{0}-\theta_{0}\right)=2000 \\
& K_{r} A=\frac{2000}{70-10}=33.3[\mathrm{kcal} / \mathrm{hr} \mathrm{deg}]
\end{aligned}
$$

でありこれらの条件をいれて（3）式の右辺第 1 項 の值を求好々 $25.8^{\circ} \mathrm{C}$ となる, また給湯開始時 $t=$ 0 の時の温度 $\theta a_{0}=70\left[{ }^{\circ} \mathrm{C}\right]$ と㧍いて積分定数 $C_{0}$ を求めると

$$
\theta_{a}=25.8+44.2 e^{-\frac{633.3}{W} t}
$$

となる。上式で $t \rightarrow \infty$ とした場合は, $\theta a_{\infty}=25.8^{\circ} \mathrm{C}$ になる。実際の浴槽への給湯の場合給湯後の熱損失も 考光，20分間における給湯の温水平均温度を $47^{\circ} \mathrm{C}$ とす ると，

$$
\frac{\theta_{a_{\circ}}-\theta_{a}}{2.3 \log \frac{\theta_{a_{0}}-\theta_{a_{\infty}}}{\theta_{a}-\theta_{a_{\infty}}}}=47-\theta_{a_{\infty}}
$$

より $\theta_{a}=33.5^{\circ} \mathrm{C}$ となる。

したがつて 20 分において平均 $47^{\circ} \mathrm{C}$ の温水を給湯でき るに值する $G_{2}$ は

$$
\theta a=25.8+44.2 e^{-\frac{633}{G_{2}} t}
$$

に扔いて $\theta_{a}=33.5, \quad \mathrm{t}=1 / 3$ とすると $G_{2}=108 \mathrm{l}$ となる。従つて少なくとも循環系保有水量は $110 l$ 以 上は必要である。しかしこの温水器の保有水量は $75 l$ であり，循環パイプ中の水量を合せても，20 分間, $200 l$ の給湯に対しては容量不足であるといえる。

しかしこれは温水器の能力不足ではなく循環水の保 有熱量の問題であるので循環系統に約 $50 l$ 程度のタン クを設けることによつて循環系保有水量も多くなるの で解決できる。

当試験に执いては，効率約60\%の水管式温水器を使 用したが，さらに効率70\%の煙管式温水器の完成をみ ているので，これを使用すればさらに好結果が得られ ると考える。

なお本実験の遂行に当たつては早稲田大学学生大 谷通，実藤征也，両君の協力を得た。付記して謝意を 表する。 


\title{
Development of Coal-fired Hot Water Boiler for Domestic Heating
}

\author{
by Takeshi Yoshida, Hisao Kawakami, Mutsuo Koizumi*
}

(Joban coal mining Co., *Waseda University)

SYNOPSIS:-T $\Delta \omega$ small hot water boilers which would be used for domestic heating and hot water supply were made. The combustion equipments of the boilers were small underfeed stokers.

The thermal efficiency of the frst boiler (water tube type) was about $60 \%$. The second boiler (smoke tube type) had more heating area than the former, and its thermal efficiency reached $70 \%$. The over-all coefficient of heat transfer was about $16.0 \mathrm{kcal} / \mathrm{m}^{2}$ $\mathrm{hr}$ deg. The hot water boiler was installed to a residence and showed good performance. 